\title{
Examining the Effect of Export Restrictions on Medical Products under WTO during Covid-19 Pandemic
}

\author{
Anand Kumar Singh \\ Assistant Professor \\ National Law University Jodhpur \\ India \\ anandksingh054@gmail.com \\ https://doi.org/10.48161/qaj.v1n3a71
}

\begin{abstract}
The world is in midst of an unprecedented public health management crisis. The worldwide demand of life-saving medical instruments and products has grown exponentially. However, the urgent supply of medical products faces the challenge of increasing export prohibitions and protectionist restrictions introduced by several developed nations to cater the demand of these products in local markets. While imposition of such restrictions may be necessary to address shortage of medical products in domestic market of such exporting countries, they severely hamper the chances of survival of many others in underdeveloped economies. The benefits of these restrictions, increased availability in the local markets and lower prices, would continue only for a limited period. In the long run, such restrictions may trigger similar response by other nations which could destabilize world trade, threaten the well-being of import-intensive sectors of domestic economy and also expose such nations to the risk of smuggling of these products elsewhere for want of higher prices. Therefore, disruption of supply chains of essential medical goods due to reckless export restrictions can be catastrophic for domestic public health sector as well as world economy. The article examines the legality and effect of these restrictions under the extant WTO framework. Lastly, the article also highlights the necessity of international cooperation between nations to overcome partisan policies of selfinterest and the importance of collective efforts in this fight against a common threat.
\end{abstract} GATT.

Keywords - Covid-19, International Trade Law, WTO,

\section{INTRODUCTION}

COVID-19 Pandemic has significantly increased the demand for medical products in various nations. This sudden increase in demand introduces a new set of economic as well as social issues. Nations depend on international trade to source such medical requirements.
However, majority of the developed nations have adopted a protectionist approach to mitigate medical shortage in their domestic market. At present, more than 80 nations have imposed export restrictions of certain sort to combat the pandemic at domestic level [1]. A restriction on the export of N95 marks by the American government, in the previous year, is one such instance of export restriction in global market [2]. Such trade restrictions severely affect the supply of medical products.

At such a juncture it becomes extremely important to analyze the legality of trade restrictions and also to ponder over various alternatives available in this regard. World Trade Organization (WTO) establishes a legal framework for the regulation of international trade in the global market. The general objective is to foster international cooperation in a sustainable manner [3]. A number of multilateral as well as plurilateral agreements function together to fulfill the main objective of WTO. General Agreement on Trade and Tariff (GATT) is the principal agreement pertaining to importation as well as exportation of medical products under COVID situation. Thus, the author would mainly focus on GATT provisions to scrutinize the legality of trade restrictions on medical products.

As a general rule, GATT imposes a ban on export restrictions. However, as an exception, member countries are allowed to impose certain restrictive measure. The author would critically analyze such GATT provisions under the second section of the article. Under the third section, the author would highlight upon various "transparency" provisions of the WTO regime. Such transparency provisions mandate a member state to provide for a detailed account of various export restrictions. Such measures would ensure a certain sense of stability in the market. Under the forth section, the author would conclude with certain viable suggestions to be adopted under such circumstance.

\section{EXPORT BAN UNDER GATT}

Under Article XI, member nations are prohibited from imposing any form of "restriction or prohibition, other than duties or any other charges" in the market [4]. Such 
restrictions include import as well as export restrictions in the market. Further, it is explicitly stated in the section that such restrictions include various measures in the form of quotas, licenses etc. Thus, members are prohibited from imposing absolute export bans. Moreover, Article XI(1) has a very broad scope. Measures not strictly amounting to an import quota or an absolute ban may also be covered under the scope of the Article. As long as a trade measure directly or indirectly restricts the imports as well as exports of a nation, the same is prohibited under the Article. Thus, a member state can very well be prohibited from imposing restriction upon exports of medical equipments under Article XI(1) of GATT.

However, GATT allows the member states to impose restrictions under certain exceptional circumstances. For the purposes of analysing trade restrictions pertaining to COVID pandemic, the author would emphasize upon measures falling under Article XI(2) as well as Article XX of GATT regime.

Exceptions provided under Article XI(2) are in addition and in exclusion to the General Exceptions provided under Article XX of GATT. Thus, such exceptions are to be established before moving on to the general exceptions of Article XX [5]. The state justifying a trade restriction has the burden to prove that the alleged measure falls under such exception.

Article $\mathrm{XI}(2)(\mathrm{a})$ is directly relevant to analyse the restrictive measure imposed under COVID pandemic. Under Article $\mathrm{XI}(2)(\mathrm{a})$, a member nation is allowed to impose trade restriction for the purposes of preventing food shortage in the domestic market [6]. For a measure to fall under Article $\mathrm{XI}(2)(\mathrm{a})$ it is important to fulfil the following two requirements-

a) That the product is indispensable to the nation exporting such product, and

b) That the concerned product must be in acute shortage in the market. Thus, the shortage must be of such nature that it causes a situation of crisis in the domestic market of the nation imposing such restriction. A determination of such crisis would be different in each and every individual case, depending upon the factual background of each case.

Above mentioned criterions are the sole guideline available to interpret the contours of the provision. However, the jurisprudence is abundantly clear that the member state must first prove a situation of crisis to invoke the exception. Thus, a member nation cannot use the provision to hoard a particular commodity to meet the eventuality of a crisis. The exception cannot be applied in a precautionary manner. Rather it is only to be implemented as a preventive action. Thus, it covers only short-term restrictions under its ambit.

Indeed, COVID pandemic has created a situation of disbalance in most of the jurisdictions. However, such disbalance has not reached to the critical point of crisis in each and every nation. In countries where the supply of such medical products has not yet reached to a critical level, export restrictions must be banned under Article XI(1). Only nations in critical requirement of medical equipments (such as COVID masks, vaccination, oxygen masks etc.) must be allowed to impose export restrictions under Article XI(2)(a).
Any other application of Article XI(2)(a) would vitiate the very purpose of Article XI itself. This would also ensure that the nations in urgent need of medical resources (generally developing as well as least developing nations) are sufficiently provided for. This would help such nations to mitigate the crisis brought about by COVID pandemic.

Exceptions provided under Article XX are not specific to any particular provision of GATT. The Article provides for eight specific grounds (a to $\mathrm{j}$ ) on the basis of which a member nation is allowed to impose a restrictive measure on imports as well as exports of various products. However, all such measures are subject to the main preambular paragraph (chapeau) of the Article. The main objective of Article XX is to maintain a proper balance between the sovereign right of each nation to implement its political goals and objectives as well as at the same time to fulfill its obligations under the GATT regime [7].

A member nation is supposed to follow a two-prong step to invoke an exception under Article XX. At first, it needs to be justified that the alleged measure falls under any of the sub-paragraphs of the article. Once, it is justified that the measure is protected under any of the sub-paragraphs then it needs to be proved that the measure is implemented in a manner compatible with Article XX Chapeau [8]. Thus, where on the one hand the sub paragraphs provide for a substantive check, the preambular paragraph imposes a procedural check on the implementation of a restrictive measure.

Majority of the nations have taken the refuge of Article $\mathrm{XX}(\mathrm{b})$ to justify the export restrictions of medical products under COVID 19 pandemic. Article XX(b) allows a member nation to implement a restrictive measure as long as the same is necessary to protect "human, animal or plant life or health"[9]. Thus, a member state needs to fulfil two important requirements to justify its measure under Article $\mathrm{XX}(\mathrm{b})-$

1. It needs to prove that there is connection between the alleged measure and human life and health, and

2. It was in fact, a matter of necessity to invoke the concerned measure.

As far as the first requirement is concerned, export restrictions against medical products do protect human life and health under Article XX(b). However, it is important to scrutinize whether such export restrictions are necessary in nature. The Appellate body has explicitly stated that the "necessary" requirement mandates a nation to balance its interest with the restrictiveness of the concerned trade measure [10]. In its subsequent decision, the Appellate Body clarified the chances of measure being justified under Article $\mathrm{XX}(\mathrm{b})$ increases with the severity of the crisis involved [11]. Further, the appellate body has imposed an additional requirement to prove "non availability" of alternative measure to establish the necessity of the concerned measure [12]. If the alternative measure happens to be more GATT consistent then it means that the state could have achieved a similar objective with reduced restrictiveness. Hence, it would render the measure to be unnecessary. However, the member nation is free to determine the degree of protection for itself. Therefore, availability of an alternative measure would be relevant only if the alternative measure happens to protect public health at a similar degree. 
COVID-19 pandemic, undoubtedly, imposes a severe danger to human health and life. Thus, it is of utmost importance to protect human life and health under such circumstances. However, the alternative measure requirement would still impose an obligation upon members to look for a less restrictive method of protecting such interest. In countries where the domestic needs are adequately fulfilled, a reasonable amount of Export restrictions against essential medical products would be a better alternative than a complete or an absolute export restriction against medical products.

It is important to understand that though Article $\mathrm{XX}(\mathrm{b})$ requires a member nation to establish the necessity of measure, it is far less stringent in comparison to Article $\mathrm{XI}(\mathrm{b})$. Thus, there are higher chances of a measure being justified under Article XX(b) than in comparison to Article $\mathrm{XI}(2)(a)$ [13]. This is so because, unlike Article XI(2)(a), there is no such mandate to establish acute shortage of medical products under Article XX(b). Further, a restriction imposed as a precautionary measure to fulfil long term requirements can still be justified under Article $\mathrm{XX}(\mathrm{b})$ but not under Article XI(2)(a).

The second limb of the two-prong test requires a member to justify a measure under the chapeau of Article XX. The main objective, under the Chapeau, is to prevent any form of "abuse of the exceptions" [14]. The chapeau ensures that a measure is not implemented in a discriminatory manner by the member state. Member states are prohibited from discriminating among states where similar conditions prevail. Two additional requirements of unjustifiable or arbitrary discrimination and disguised restriction are imposed under the Chapeau [15]. The justifiability of a discriminatory measure is understood from the context of the cause of the measure so imposed. Further, the terms unjustifiable discrimination and disguised restrictions import a similar essence to ensure a legitimate connection between the cause and implementation of the concerned measure.

Most of the export restrictions, imposed under the COVID pandemic, adequately fulfil the requirements so provided under the Chapeau of GATT Article XX. There exists a general consensus about the urgency of pandemic. Thus, there is no unilateral implementation of a particular restriction against a particular nation. Therefore, the main requirement is to prove the necessity requirement of Article $\mathrm{XX}(\mathrm{b})$ to take the refuge of General Exceptions. The general application of Article XX would depend on factors such as the population size of a nation, demographic reality of a nation, supply of medical products in the nation etc.

\section{TRANSPARENCY UNDER WORLD TRADE ORGANISATION}

COVID pandemic introduces a new challenge of uncertainty among various nations. A rapid increase in export restrictions brings in its own set of issues pertaining to unpredictability. In such a situation it becomes extremely pertinent to increase transparency and accountability within the International Trade regime. Thus, the author would scrutinize the transparency mechanism under WTO to assess the stability of the situation.

Transparency requirement is manifested in various form under the WTO framework. A mandate of publication, notification, assessment etc. fulfill the basic transparency requirement under WTO regime [16]. In 2012, a report titled "Decisions on Notification Procedure for Quantitative Restriction" was published [17]. It imposes an obligation on the member states to notify the Secretariat about various quantitative restrictions imposed in a year. Every second year a member nation is under an obligation to furnish such reports. Members are also required to report temporary measures while notifying the secretariat. Such reports are regularly updated and placed before the Market Access Committee. It is with the help of this Quantitative Restriction (QR) decision that various COVID 19 related restrictions were notified to the WTO. WTO has used such notifications to publish its own reports on the impact of COVID-19 on global trade [18]. A member nation is supposed to furnish all relevant information (from the specificities of the product involved to the duration of the restriction) through such notifications.

In addition to the Quantitative Restriction notification, a member state is also under an obligation to furnish a report on restrictions imposed under GATT Article XI(2)(a) to the Committee on Agriculture. This obligation arises under Article 12 of the Agreement on Agriculture [19]. A member imposing such restriction is also supposed to furnish a report on the possible impact that the restriction would have on the food security of the importing member state.

Above mentioned obligations to notify ensure a total transparency under the WTO mechanism. It would provide for an adequate platform to share information and enhance predictability in an environment of COVID pandemic. A regular notification would also enable the WTO mechanism to govern such restrictions in a better manner. For a smooth conduct of international trade and for a future hope for international cooperation it is a pre-requisite to ensure a proper transparency under the trading regime. Under the pandemic situation transparency becomes a matter of urgency.

\section{CONCLUSION}

A robust as well as a transparent mechanism is the only way forward to combat the menace of the pandemic at a global level. A protectionist approach would only further aggravate the problem. Export restrictions on medical products are justified only when it is necessary to fulfill the domestic needs of a nation. A member nation must not hoard medical products to fulfill its long terms requirements. International cooperation of various nations is a pre-requisite to maintain a regular supply of medical products in various nations.

GATT provisions aim towards a sustainable model of development. It is for this reason that it maintains a balance between the demands of sovereignty and the demands of building a global community. Trading blocks need to protect this balance to mitigate the impact of current crisis. A recent attempt on the part of G20 nations to develop trade and reduce unnecessary export restrictions is one such step in the direction of right balance [20]. This should encourage several Regional blocks as well as Custom Unions to further integrate the economic market. It is not the mysticism of an invisible hand that we need to rely upon. Rather it is the explicit recognition of global identity that can guide us through the COVID 19 pandemic. 


\section{REFERENCES}

[1] WTO Secretariat. (2021, February). COVID 19: Measures
Affecting Affecting Trade
https://www.wto.org/english/tratop_e/covid19_e/trade_related_go ods measure e.htm.

[2] WTO Secretariat. (2020, May). Notification Pursuant To The Decision On Notification Procedures For Quantitative Restrictions- USA.

[3] WTO Agreement: Marrakesh Agreement Establishing the World Trade Organization, Apr. 15, 1994, 1867 U.N.T.S. 154, 33 I.L.M. 1144.

[4] GATT 1994:General Agreement on Tariffs and Trade 1994, Apr. 15, 1994, Marrakesh Agreement Establishing the World Trade Organization, Annex 1A, 1867 U.N.T.S. 187, 33 I.L.M. 1153. Art. XI.

[5] Dispute Settlement Body. (2012, January). China - Measures Related to the Exportation of Various Raw Materials (WT/DS394/20).

[6] GATT 1994. Article XI(2)(a).

[7] Dispute Settlement Body. (2019, January). United States Measures Concerning The Importation, Marketing And Sale Of Tuna And Tuna Products Appellate Body Report And Panel Report Pursuant To Article 21.5 Of The DSU (WT/DS381/49/Rev.1). World Trade Organisation. https://docs.wto.org/dol2fe/pages/ss/directdoc.aspx ?filename=q:/ wt/ds/381-49r1.pdf\&open=true.

[8] Appellate Body Report. (2001, October). United States - Import Prohibition Of Certain Shrimp And Shrimp Products (WT/DS58/AB/RW). World Trade Organisation. https://docs.wto.org/dol2fe/Pages/SS/directdoc.aspx?filename=Q: /WT/DS/58ABRW.pdf\&Open=True.

[9] GATT 1994. Article XX(b).

[10] Appellate Body Report. (2007, December). Brazil - Measures Affecting Imports Of Retreaded Tyres (WT/DS332/AB/R). World Trade Organisation. https://docs.wto.org/dol2fe/Pages/SS/directdoc.aspx?filename=Q: /WT/DS/332ABR.pdf\&Open=True.

[11] Appellate Body report. (2001, March). European Communities Measures Affecting Asbestos And Asbestos-Containing Products
(WT/DS135/AB/R). World Trade Organisation. https://docs.wto.org/dol2fe/Pages/SS/directdoc.aspx?filename=Q: /WT/DS/135ABR.pdf\&Open=True

[12] Appellate Body Report. (2000, December). Korea - Measures Affecting Imports Of Fresh, Chilled And Frozen Beef(WT/DS161/AB/R, WT/DS169/AB/R). World Trade Organisation.

https://docs.wto.org/dol2fe/Pages/SS/directdoc.aspx?filename=Q: /WT/DS/169ABR.pdf\&Open=True.

[13] Aatreya, Siddhartha. (2020, April 25). Are COVID-19 Related Trade Restrictions WTO-Consistent? EJIL:TALK!. https://www.ejiltalk.org/are-covid-19-related-trade-restrictionswto-consistent/. [14] Appellate Body Report. (1996, April). United States - Standards for Reformulated and Conventional Gasoline (WT/DS2/AB/R). World Trade Organisation.https://docs.wto.org/dol2fe/Pages/SS/directdoc.aspx ?filename=Q:/WT/DS/2ABR.pdf\&Open=True.

[15] GATT 1994. Article XX Chapeau.

[16] WTO Secretariat. (2020, April 23). Export Prohibitions and Restrictions- Information Note. https://www.wto.org/english/tratop_e/covid19_e/export_prohibiti ons_report_e.pdf.

[17] Council for Trade in Goods. (2012, July). Decision On Notification Procedures For Quantitative Restrictions (G/L/59/Rev.1). World Trade Organisation. https://docs.wto.org/dol2fe/Pages/FE_Search/FE_S_S009DP.aspx ?language $=E \&$ CatalogueIdList $=100295,8140,7504,24647,5803 \&$ CurrentCatalogueIdIndex $=0 \&$ FullTextHash $=$

[18] World Trade Organisation Secretariat. (2020, September). How WTO Members have used Trade Measures to Expedite Access to Covid-19 Critical Medical Goods And Services. https://www.wto.org/english/tratop_e/covid19_e/services_report_ 16092020_e.pdf

[19] Agreement on Agriculture, Marrakesh Agreement Establishing the World Trade Organization, Annex 1A, 1867 U.N.T.S. 410, Article 12.

[20] Post, T. J. (2020, May 15). G20 vows to avoid "unnecessary" trade barriers. The Jakarta Post. https://www.thejakartapost.com/news/2020/05/15/g20-vows-toavoid-unnecessary-trade-barriers.html 